\title{
Implications of Using Host Response-Based Molecular Diagnostics on the Management of Bacterial and Viral Infections: A Review
}

\author{
Johnny Atallah ${ }^{1,2}$ and Michael K. Mansour ${ }^{1,2 *}$ \\ 'Division of Infectious Diseases, Massachusetts General Hospital, Boston, MA, United States, ${ }^{2}$ Department of Medicine, \\ Harvard Medical School, Boston, MA, United States
}

OPEN ACCESS

Edited by:

Hadi M. Yassine

Qatar University, Qatar

Reviewed by:

Nicolas Leveque,

University of Poitiers, France

Hossein Yousofi Darani

Isfahan University of Medical

Sciences, Iran

Meghna Verma,

AstraZeneca, United States

${ }^{*}$ Correspondence:

Michael K. Mansour

mkmansour@mgh.harvard.edu

Specialty section:

This article was submitted to

Precision Medicine,

a section of the journal

Frontiers in Medicine

Received: 29 October 2021

Accepted: 03 January 2022

Published: 03 February 2022

Citation:

Atallah J and Mansour MK (2022)

Implications of Using Host

Response-Based Molecular

Diagnostics on the Management of

Bacterial and Viral Infections: A

Review. Front. Med. 9:805107.

doi: 10.3389/fmed.2022.805107
Host-based diagnostics are a rapidly evolving field that may serve as an alternative to traditional pathogen-based diagnostics for infectious diseases. Understanding the exact mechanisms underlying a host-immune response and deriving specific host-response signatures, biomarkers and gene transcripts will potentially achieve improved diagnostics that will ultimately translate to better patient outcomes. Several studies have focused on novel techniques and assays focused on immunodiagnostics. In this review, we will highlight recent publications on the current use of host-based diagnostics alone or in combination with traditional microbiological assays and their potential future implications on the diagnosis and prognostic accuracy for the patient with infectious complications. Finally, we will address the cost-effectiveness implications from a healthcare and public health perspective.

Keywords: infections, host-response, biomarkers, proteomics, transcriptomics, RT-PCR

\section{INTRODUCTION}

The complexity of the human immune response in the setting of disease has made it difficult to assign the contribution from the underlying pathologic process in the background of the host immune response. The difficulty in such determination frequently leads to misdiagnoses, antibiotic misuse leading to antimicrobial resistance (AMR), increased healthcare expenses and direct adverse effects affecting the health of patients.

The clinical manifestations of pathogen-specific disease vary across a wide spectrum of symptoms including fever, myalgias, respiratory symptoms, weakness and altered mental status among many others. In fact, pathogen-based diagnostic testing has been the traditional and a convenient method for the identification of the causative pathogen linked with specific clinical manifestations, such as fever. This process is usually performed using traditional based culture systems, immunoassays, and molecular-based testing. Pathogen detection can usually be achieved by polymerase chain reaction (PCR) that can amplify the nucleic acid of pathogens directly from blood culture. However, a limitation to PCR is the necessity for a minimum pathogen burden in the bloodstream, which in turn results in several false-negative outcomes. Another limitation is the time constraint on laboratory staff performing repeat pathogen-based diagnostics in an attempt to improve sensitivity and detection.

The purpose of the immune system is to recognize and eliminate invading pathogens making a host response-based immunodiagnostic an attractive adjunct to pathogen-based diagnostics 
with the potential for improved diagnostics accuracy and efficiency. These techniques represent a step closer toward precision and personalized medicine capable of providing the best treatment matched for the specific patient in a timely manner (1). As such, the "omics" platforms have proliferated around host immunodiagnostics and several promising molecular host biomarkers show potential in the rapid diagnosis in critical diseases (2). Unlike pathogen-based testing, host immunodiagnostics present the capability of differentiating non-infectious immune triggers including sterile inflammatory processes, autoimmune diseases, or malignancy.

These techniques involve platform assays such as RT-PCR, RNA sequencing and others to test for specific host gene expression signatures and transcripts as well as metabolic and protein biomarkers directly related to susceptibility and response to infection. These technological advances have made it possible to integrate multiple biomarkers into single predictive models, and thus there is progress in the integration of genomics, transcriptomics, and proteomics with recent expansion into epigenomics, lipidomics, and metabolomics (3). While these approaches have the prospect of a more precise identification of an infectious trigger based on the host immune response, none to date have undergone clinical trial testing or achieved approval for clinical application.

Here, we review the current state of novel host response-based diagnostic testing on the identification of the causative processes underlying an activated immune response, on the influence on patient outcome, on reduction of healthcare cost, and on the possibility of redefining the standard of care for specific clinical presentations. This article will shed light on possible benefits of using host-based diagnostics from a public health perspective regarding pandemics and endemics, and finally, we examine techniques of integrating both, host-based and pathogen-based diagnostics for improving clinical outcomes.

\section{METHODS}

Publications on host immune response and role of immune based diagnostics were collected from the PubMed database. $\mathrm{MeSH}$ terms included host response, immune based diagnostics, transcriptomics, proteomics, infection, and sepsis were used to conduct this search. The articles were reviewed by the authors. Articles were limited to English language only and results were filtered by date of publication to include all articles published from 2015 through 2021.

\footnotetext{
Abbreviations: AMR, Antimicrobial resistance; AUROC, Area under the receiver operating characteristic curve; CAP, Community acquired pneumonia; PSI, Pneumonia severity index; RSV, Respiratory syncytial virus; RT-PCR, Real time polymerase chain reaction; LRTI, Lower respiratory tract infection; CRP, CReactive protein; FAM89A, Family With Sequence Similarity 89 Member A; IFI44L, Interferon Induced Protein 44 Like; mNGS, Metagenomics next generation sequencing; Tb, Tuberculosis; ED, Emergency Department; WHO, World Health Organization; NPV, Negative predictive value; PPV, Positive predictive value; PCT, Procalcitonin; IMKX-BWN-1, Inflammatix-bacterial-viral-non-infected-version 1; NAAT, Nucleic acid amplification test; RT-LAMP, Reverse transcription loopmediated isothermal amplification; NTS, Nose and throat swabs; IP-10, InterferonInducible Protein 10; BCA-1, B-Cell attracting chemokine; OASL, Oligoadenylate synthetases-like; NP, Nasopharyngeal samples.
}

\section{RESULTS}

\section{Host-Based Diagnostics for Identifying the Infectious Etiology}

The initial management of suspected infection is pathogen identification, which subsequently dictates the treatment approach. In this section, we will review the use of host-based diagnostics in determining and identifying the infectious etiology. MeSH terms yielded 12 studies.

The host response to bacterial vs. viral test was examined. The study compared transcriptional analysis to a host immune biomarker, procalcitonin (PCT), which rises in the setting of bacterial but not viral infection (4). Results of the BioFire FilmArray system using RT-PCR to measure 45 transcript signatures were compared to standard PCT, yielded accurate discrimination between bacterial and viral infections superior to PCT performance. Six hundred twenty-three subjects with suspected respiratory infection or sepsis had blood testing for transcriptional profiling. The results provided $80.1 \%$ accuracy for bacterial infection and $86.8 \%$ accuracy for viral infection with a mean turnaround time of $\sim 45$ min compared to an accuracy of $68.7 \%$ for PCT alone (5). In addition to accurately detecting infectious processes, the BioFire FilmArray correctly identified ill patients without infection (no positive microbiology) with an $86 \%$ accuracy (6).

Several studies focused on using detection of host mRNA signatures to differentiate infectious from non-infectious processes in patients with acute infections and sepsis. The InSep $^{\text {TM }}$ test (Inflammatix, Burlingame, CA, formerly known as HostDx ${ }^{\text {TM }}$ Sepsis) is a 29-host mRNA blood-based test that allows for rapid diagnosis of acute infections and sepsis using machine-learning algorithms. The patterns interpreted using InSep allows for differentiation of acute host response to bacterial vs. viral infections as well as prognosticating disease severity using whole blood. Following whole blood RNA extraction from patients with suspected sepsis in the emergency department, amplifying and quantitating the 29-mRNAs; these transcriptional signatures are then fed into machine learning algorithms to produce measurable scores. The 3 measurable scores (scale from 0 to 40 ) assess the likelihood of bacterial infection, the likelihood of viral infection, and the infection severity prediction score. However, one limitation is that some of the information presented was in some cases preliminary or hypothetical. An attractive feature of the InSep test is a rapid turnaround time of $<30 \mathrm{~min}$.

The 29 mRNAs that the InSep test consists of are classified into 3 separate, validated subpanels: a 7-mRNA "BacterialViral Metascore," an 11-mRNA "Stanford Mortality Score" and an 11-mRNA "Sepsis Metascore." The 7-gene "Bacterial-Viral Metascore" subpanel consists of 4 genes (HK3, TNIP1, GPAA1, and CTSB) that have shown to be significantly higher in bacterial infections, and 3 genes (IFI27, JUP, and LAX1) shown to be higher in viral infections. The "Sepsis Metascore" subpanel on another hand, consists of a sepsis-specific transcripts including CEACAM1, C3AR1, GNA15, and HLA-DPB1 which have previously been linked to sepsis. Furthermore, neutrophil-related antimicrobial proteins genes such as DEFA4, CTSG, MPO, and 
BPI constitute the "Stanford Mortality Score" subpanel, along with additional genes related to energy metabolism and hypoxia (TRIB1, HIF1A, and NDUFV2).

Given the breadth of signatures included in the InSep platform, the potential exists to differentiate detection of bacterial or viral infection. The authors propose that application of RNA transcriptional analysis early in the presentation of a patient with a suspected infection reduces the ordering of multiple unnecessary diagnostics (7). The InSep assay showed a specificity of $98 \%$ and a sensitivity of $94 \%$ for detecting bacterial infections, and a specificity of $93 \%$ and a sensitivity of $96 \%$ for viral infections (8).

A similar platform using 29 host mRNA signatures analysis, a neural network classifier: Inflammatix-Bacterial-Viral-Noninfected-Version 1 (IMX-BWN-1) shows similar discriminatory results. The IMX-BVN-1 was used to assess patients with presumed infection and sepsis through the combination of mRNA host-response profiling combined with a machine learning algorithm. IMX-BWN-1 showed excellence diagnostic accuracy for bacterial and viral infection differentiation with a sensitivity of $97 \%$ and a specificity of $99 \%$. The area under the curve (AUROC) for IMX-BWN-1 for identifying bacterial infections and viral infections was 0.87 and 0.86 , respectively. The combination of mRNA expression analysis and machine learning proved superior to classic infection biomarkers such as PCT with an AUROC of 0.83 for bacterial infections and 0.27 for viral infections, and C-reactive protein (CRP) with an AUROC of 0.7 for bacterial infections and 0.38 for viral infections $(9,10)$.

In another pooled analysis of 1,057 samples from 20 cohorts, a set of 7 genes was derived for discriminating bacterial and viral infections. The 20 cohorts that were included either bacterial or viral infections, but not both. These cohorts represent a wide variety of clinical conditions, including a range of infection types (gram-positive, gram-negative, atypical bacteria, common respiratory viruses) as well as a range of severities (from mild infections to severe septic shock). This multicohort analysis aimed to use gene expression datasets for identifying a biomarker that can discriminate between viral and bacterial infections. Using this set alongside the 11-gene Sepsis MetaScore (Please see section "d" for more information) yielded a sensitivity of $94 \%$ and a specificity of $59.8 \%$ for identifying bacterial infections (11).

\section{Infectious Etiology in the Pediatric Population}

Infections are a leading cause for life-threatening events in the pediatric population. The WHO reports a global mortality rate of 5.9 million children under the age of 5 due to infections (12). Thus, host-response assays have emerged as promising diagnostics in this population.

In a prospective observational study febrile infants 60 days or younger were enrolled. The transcriptional assessment of 66 genes accurately identified infants with bacterial infections with a sensitivity of $87 \%$ and a specificity of $89 \%$. Moreover, when 66 genes were reduced to 10 classifier genes, data continued to yield high diagnostic performance with a sensitivity of $94 \%$ and a specificity of $95 \%$ in distinguishing bacteremia in infants from those without infection as compared to confirmed bacterial blood cultures (13).
Furthermore, in a similar study, total blood RNA expression signature for distinguishing bacterial from viral infection in febrile children was compared with clinical and microbiological diagnostics. Subjects were classified into one of 3 groups: definite bacterial infection, definite viral infection and indeterminate state. These groups were stratified by culture or molecular detection of pathogens A two-transcript RNA signature (FAM89A and IFI44L) was identified from a larger 38-transcript screen. Then, the performance of a 2-transcript RNA signature expression was evaluated among the groups. The Family with Sequence Similarity 89 Member A (FAM89A) and the Interferon Induced Protein 44 Like (IFI44L) are both protein coding genes that have been linked to a rare mild immunodeficiency (immunodeficiency 38 with basal ganglia calcification). Upon implementation, this 2-transcript signature yielded favorable results for detection of definite bacterial with a sensitivity of $100 \%$, and a specificity of $96.4 \%$ and definite viral with a sensitivity of $100 \%$, and a specificity of $97.1 \%$. IFI44L and FAM89A expression values were combined into a disease risk score. IFI4L was noted to be increased in antiviral responses mediated by interferons, while FAM89A was increased in bacterial infections and septic shock thus forming a reciprocal relationship of upregulation between both genes in viral and bacterial infections.

One interesting outcome was regarding the indeterminate groups where the 2-transcript signature detected $46.3 \%$ of those cases as having bacterial infection although $94.9 \%$ received antibiotic treatment by standard care $(14,15)$.

This 2-gene signature was further validated when applied to data from the RNA expression signatures used by the study described above. This validation study aimed to assess the accuracy of the 2-gene signature, previously tested in children with a mean age of 19 months, in infants aged 60 days or younger. The results were promising and showed a sensitivity of $88.8 \%$ and a specificity of $93.7 \%$ when compared to definite bacterial infections with positive cultures and confirmed viral infections. These data demonstrate the translatable potential of this 2-gene transcript signature into a simple bedside diagnostic test although a larger sample of subjects is needed for confirmation (16).

The application of technology amenable to bedside conditions show promise as a point of care RNA diagnostic. Use of reverse transcription-loop mediated isothermal amplification (RT-LAMP) technology demonstrated that the 2-gene RNA signature has the potential of being translated into a rapid and portable platform convenient for the use as a point-of-care test. A laboratory-on-a-chip platform that uses reverse transcriptionloop mediated isothermal amplification (RT-LAMP) technology. RT-LAMP technology uses the mechanism of auto cycling strand displacement DNA synthesis using a polymerase with 2 pairs of primers used. Using 6 independent sequences at the start and 4 independent sequences toward the latter stages, RT-LAMP can recognize and amplify target sequences. This RT-LAMP uses numerous microsensors that can detect hydrogen ions released and thus detect changes in $\mathrm{pH}$ during NAAT under same experimental conditions of the previous studies (14-16). The results of translating this 2-gene signature to RT-LAMP were very similar to using microarray data used in the previous 
studies. Sensitivity and specificity were $100 \%$ for confirmed viral and bacterial infections. In addition to RT-LAMP platform being simple, the assay time required was $<25 \mathrm{~min}$ which is considerably more rapid than microarray (17).

The application of RNA signatures to determine microbial composition and prognostic outcomes has been examined. In a retrospective study aiming to evaluate the use of microbial signatures of specific microbiota to prognosticate the severity of influenza virus infection, 36 pediatric (mean age of 3 years) subjects infected with influenza and presenting with symptoms for $<2$ days were recruited. RNA-gene sequencing, mNGS and computational analysis workflow were used to assess nasopharyngeal samples (NP) collected from these subjects. Results indicated that subjects having an increased bacterial diversity in their NP samples experienced milder disease. On the contrary, subjects with diminished abundance of $S$. aureus on one hand, and increased presence of Streptobacillus, Prevotella, Porphyromonas, Granulicatealla, Veillonella, Fusobacterium, and Haemophilus in their NP samples experienced severe respiratory or neurological influenza outcomes. These data demonstrate that use of RNA transcript as a reflection of microbiome diversity in the setting of influenza can potentially serve as an accurate prognostic indicator (18) (see Table 1).

Some limitations arise due to the special considerations of the pediatric population, which include difficulty of sample collection. In addition, some studies aimed to recruit equal numbers of children with confirmed bacterial and viral infections and then assess for diagnostic accuracy of the hostresponse assay. Thus, a limitation around possible bias in misrepresentation of infectious etiology and frequency in febrile children presenting to healthcare facilities.

\section{Host-Based Diagnostics for Identifying Respiratory Infections Respiratory Infections}

One of the most common causes of hospitalization and mortality in adults is lower respiratory tract infection (LRTI). Evaluation of whole blood gene expression profiling using RNA sequencing and $\mathrm{qPCR}$ for the discrimination bacterial from non-bacterial infection was performed. Using MeSH terms for host-based diagnostics for identifying bacterial vs. viral respiratory infections including tuberculosis yielded 13 studies.

Despite being a common cause of morbidity, mortality and hospitalization, LRTI-causing pathogens are infrequently identified due to limitations of traditional pathogen-based detection methods. In one study, an 11-host gene pathway set from nose and throat swabs, sputum, urine, and blood samples obtained from potential patients with symptoms of LRTI was used as an optimal marker. Quantitative PCR assay [e.g., Film Array Respiratory Panel, Idaho Technologies Inc. for nose and throat swabs (NTS) and sputum] was used for all the samples, and the difference in gene expression was tested by Wilcoxon Rank test. The Respiratory Panel offers a run time of about $45 \mathrm{~min}$ for rapid PCR detection of respiratory infections, and it integrates sample purification, amplification, detection, and analysis in one automated multiplex PCR system for detection of many pathogens within rapid time. RNA sequencing was also used and differences in gene expression between bacterial and non-bacterial infected subjects were assessed by a similar statistical approach. The results of this study showed promising outcomes with a sensitivity of $90 \%$ and a specificity of $83 \%$ for identifying bacterial LRTI as compared to confirmed microbiological testing (19).

Other studies have utilitzed metagenomic next-generation sequencing (mNGS) for DNA and RNA (see section "f" for more information) to define host signatures in response etiologic pathogens resulting in LRTI. In a prospective observational study comparing mNGS from patients with and without LRTI to traditional assays, this novel host-based platform detected more viruses and fungi and at a more rapid rate with an approximate 2-day turnaround time. It showed a positive predictive value (PPV) of $78.5 \%$, sensitivity of $66.7 \%$ and specificity of $75.4 \%$. Such results will provide insight regarding the impact of the host transcriptome data in the accurate diagnosis of LRTI (20).

In addition to PCR and transcriptional analysis, circulating host biomarker have also been explored as diagnostic and prognostic indicators of infection. One such molecular is proadrenomedulin, a receptor expressed on myeloid cells showing encouraging results for predicting complicated community acquired pneumonia (CAP) in the pediatric population. Proadrenomedullin is a member of the calcitonin peptide family that has been shown to be expressed proportionately during severe infections and is widely expressed by many tissues and organs. It increases microvasculature flow to maintain adequate vascular supply to vital organs during sepsis (21). A proadrenomedullin level above $0.16 \mathrm{nmol} / \mathrm{L}$ generated using TRACE (time-resolved amplified cryptase emission) showed a sensitivity of $100 \%$ and a specificity of $70 \%$ for bacteraemia in children (0-18 years of age) presenting with community acquired pneumonia $(22,30)$.

The evaluation of proadrenomedullin in the assessment of adult patients with CAP shows similar results when compared to pneumonia severity index (PSI) and CURB65 scores, as a prognostic indicator. Eighty-one patients with suspected CAP were enrolled and followed up to a 28-day duration. Results showed an increased prognostic accuracy for CAP when CURB65 scores were used in combination with proadrenomedullin levels. In fact, for the highest risk patients with upper score classes of PSI and CURB65, proadrenomedullin levels provided additional risk stratification. This result provided valuable accuracy and guidance to the patients' need for intubation, non-invasive ventilation and ICU admission. Using specific proadrenomedullin levels for predicting outcomes yielded a sensitivity of $77.8 \%$ and a specificity of $76.5 \%$ for death when the value is $1.6 \mathrm{nmol} / \mathrm{L}$, a sensitivity of $83.3 \%$ and a specificity of $88.7 \%$ for endotracheal intubation when the value is 2.4 $\mathrm{nmol} / \mathrm{L}$, and a sensitivity of $87.5 \%$ and a specificity of $77 \%$ for non-invasive mechanical ventilation at a value of $1.5 \mathrm{nmol} / \mathrm{L}$ (31).

\section{Coronavirus Disease 2019}

SARS-CoV-2 is the causative respiratory viral pathogen responsible for the COVID-19 (32). Given the need for rapid diagnostics, multiple studies explored the use of host-based 
TABLE 1 | Use of host-response diagnostics for discrimination of bacterial vs. viral infections.

\begin{tabular}{|c|c|c|c|c|c|c|c|c|c|c|}
\hline References & Objective & Assay & Comparison & Genes & Sample size & Sensitivity & Specificity & PPV & NPV & Notes \\
\hline $\begin{array}{l}\text { Tsalik et al. (5) } \\
\text { de Jonge et } \\
\text { al. (4) }\end{array}$ & $\begin{array}{l}\text { Bacterial vs. } \\
\text { viral } \\
\text { discrimination }\end{array}$ & $\begin{array}{l}\text { BioFire FilmArray } \\
\text { system using } \\
\text { RT-PCR }\end{array}$ & PCT & $\begin{array}{l}45 \text { transcript } \\
\text { signatures }\end{array}$ & $\begin{array}{l}623 \text { adults } \\
\text { with } \\
\text { suspected } \\
\text { respiratory } \\
\text { infections }\end{array}$ & - & $\begin{array}{l}80.1 \% \text { for bacterial } \\
86.8 \% \text { for viral } \\
86 \% \text { for } \\
\text { no infection }\end{array}$ & - & - & $\begin{array}{l}\text { Turnaround time of } 45 \\
\text { min }\end{array}$ \\
\hline $\begin{array}{l}\text { Ducharme et } \\
\text { al. (7) } \\
\text { Safalika et al. } \\
\text { (8) }\end{array}$ & $\begin{array}{l}\text { Infectious vs. } \\
\text { non-infectious } \\
\text { discrimination }\end{array}$ & $\begin{array}{l}\text { InSep Test using } \\
\text { whole blood } \\
\text { mRNA for host } \\
\text { mRNA signatures }\end{array}$ & $\begin{array}{l}\text { Traditional } \\
\text { microbiology } \\
\text { assays }\end{array}$ & $\begin{array}{l}\text { 29-host } \\
\text { mRNA } \\
\text { signatures }\end{array}$ & - & $\begin{array}{l}98 \% \text { for } \\
\text { bacterial } \\
93 \% \text { for viral }\end{array}$ & $\begin{array}{l}94 \% \text { for bacterial } \\
96 \% \text { for viral }\end{array}$ & - & - & $\begin{array}{l}\text { Turnaround time of } 30 \\
\text { min }\end{array}$ \\
\hline $\begin{array}{l}\text { Mayhew (9) } \\
\text { Bauer et al. } \\
\text { (10) }\end{array}$ & $\begin{array}{l}\text { Bacterial vs. } \\
\text { viral } \\
\text { discrimination }\end{array}$ & $\begin{array}{l}\text { IMX-BWN-1 using } \\
\text { whole blood } \\
\text { mRNA for host } \\
\text { mRNA signatures }\end{array}$ & $\begin{array}{l}\text { Traditional } \\
\text { microbiology } \\
\text { assays + } \\
\text { PCT + CRP }\end{array}$ & $\begin{array}{l}\text { 29-host } \\
\text { mRNA } \\
\text { signatures }\end{array}$ & $\begin{array}{l}1,069 \text { adults } \\
\text { with } \\
\text { suspected } \\
\text { infections }\end{array}$ & $97 \%$ & $99 \%$ & - & - & $\begin{array}{l}\text { Performance superior } \\
\text { to PCT and CRP }\end{array}$ \\
\hline $\begin{array}{l}\text { Sweeney et } \\
\text { al. (11) }\end{array}$ & $\begin{array}{l}\text { Bacterial vs. } \\
\text { viral } \\
\text { discrimination }\end{array}$ & $\begin{array}{l}\text { Multicohort } \\
\text { analysis using } \\
\text { gene expression } \\
\text { datasets to derive } \\
\text { a biomarker }\end{array}$ & & $\begin{array}{l}\text { 7-gene } \\
\text { dataset }\end{array}$ & $\begin{array}{l}1,057 \text { adults } \\
\text { with } \\
\text { suspected } \\
\text { infections }\end{array}$ & $94 \%$ & $59.8 \%$ & - & - & - \\
\hline $\begin{array}{l}\text { Mahajan et al. } \\
\text { (13) }\end{array}$ & $\begin{array}{l}\text { Detection of } \\
\text { Bacterial } \\
\text { infections in } \\
\text { febrile infants } \\
60 \text { days or } \\
\text { younger }\end{array}$ & $\begin{array}{l}\text { Transcriptional } \\
\text { assessment of } \\
\text { RNA biosignatures }\end{array}$ & $\begin{array}{l}\text { Traditional } \\
\text { microbiology } \\
\text { assays }\end{array}$ & $\begin{array}{l}\text { 10-classifier } \\
\text { genes }\end{array}$ & $\begin{array}{l}279 \text { randomly } \\
\text { selected } \\
\text { febrile infants }\end{array}$ & $94 \%$ & $95 \%$ & - & - & - \\
\hline $\begin{array}{l}\text { Herberg et al. } \\
\text { (15) }\end{array}$ & $\begin{array}{l}\text { Bacterial vs. } \\
\text { viral infection } \\
\text { in febrile } \\
\text { children }\end{array}$ & Microarray & $\begin{array}{l}\text { Traditional } \\
\text { microbiology } \\
\text { assays and } \\
\text { clinical } \\
\text { assessment }\end{array}$ & $\begin{array}{l}\text { 2-gene } \\
\text { transcript } \\
\text { signature }\end{array}$ & $\begin{array}{l}455 \text { children } \\
\text { with fever }\end{array}$ & $\begin{array}{l}100 \% \text { for } \\
\text { bacterial } \\
100 \% \text { for viral }\end{array}$ & $\begin{array}{l}96.4 \% \text { for bacterial } \\
97 . \% \text { for viral }\end{array}$ & - & - & $\begin{array}{l}\text { The 2-transcript gene } \\
\text { signature detected } \\
46.3 \% \text { of indeterminate } \\
\text { subjects as having } \\
\text { infection although } \\
94.9 \% \text { received } \\
\text { antibiotics as per } \\
\text { standard care. }\end{array}$ \\
\hline $\begin{array}{l}\text { Kafourou et } \\
\text { al. (16) }\end{array}$ & $\begin{array}{l}\text { Bacterial vs. } \\
\text { viral infection } \\
\text { in febrile } \\
\text { infants }<60 \\
\text { days old }\end{array}$ & Microarray & $\begin{array}{l}\text { Traditional } \\
\text { microbiology } \\
\text { assays and } \\
\text { clinical } \\
\text { assessment }\end{array}$ & $\begin{array}{l}\text { 2-gene } \\
\text { transcript } \\
\text { signature }\end{array}$ & $\begin{array}{l}279 \text { randomly } \\
\text { selected } \\
\text { febrile infants }\end{array}$ & $88.8 \%$ & $93.7 \%$ & - & - & $\begin{array}{l}\text { Potential of being used } \\
\text { as a simple bedside } \\
\text { diagnostic test }\end{array}$ \\
\hline $\begin{array}{l}\text { Pennisi et al. } \\
\text { (17) }\end{array}$ & $\begin{array}{l}\text { Bacterial vs. } \\
\text { viral infection } \\
\text { in febrile } \\
\text { children }\end{array}$ & RT-LAMP & $\begin{array}{l}\text { Traditional } \\
\text { microbiology } \\
\text { assays and } \\
\text { clinical } \\
\text { assessment }\end{array}$ & $\begin{array}{l}\text { 2-gene } \\
\text { transcript } \\
\text { signature }\end{array}$ & $\begin{array}{l}455 \text { children } \\
\text { with fever }\end{array}$ & $100 \%$ & $100 \%$ & - & - & $\begin{array}{l}\text { Turnaround time of } \\
25 \text { min significantly } \\
\text { faster than microarray }\end{array}$ \\
\hline
\end{tabular}


TABLE 2 | Results of using host-response diagnostics for identifying respiratory infections.

\begin{tabular}{|c|c|c|c|c|c|c|c|c|c|c|}
\hline References & Objective & Assay & Comparison & Genes & Sample size & Sensitivity & Specificity & PPV & NPV & Notes \\
\hline $\begin{array}{l}\text { Bhattacharya et al. } \\
\text { (19) }\end{array}$ & $\begin{array}{l}\text { Identifying } \\
\text { bacterial LRTI }\end{array}$ & $\begin{array}{l}\text { PCR assays and } \\
\text { RNA sequencing }\end{array}$ & Standard of care & 11 gene pathways & $\begin{array}{l}94 \text { adults with } \\
\text { suspected LRTI }\end{array}$ & $90 \%$ & $83 \%$ & - & - & $\begin{array}{l}\text { Turnaround time of } \\
45 \mathrm{~min}\end{array}$ \\
\hline Chen et al. (20) & Diagnosing LRTI & mNGS & $\begin{array}{l}\text { Traditional } \\
\text { microbiological } \\
\text { assays }\end{array}$ & & $\begin{array}{l}162 \text { adults with } \\
\text { and without LRTI }\end{array}$ & $66.7 \%$ & $75.4 \%$ & $78.5 \%$ & - & - \\
\hline $\begin{array}{l}\text { Alcoba et al. (21) } \\
\text { Saleh et al. (22) }\end{array}$ & $\begin{array}{l}\text { Diagnosing } \\
\text { bacteremia in } \\
\text { children (0-18 } \\
\text { years old) } \\
\text { presenting with } \\
\text { community } \\
\text { acquired } \\
\text { pneumonia }\end{array}$ & TRACE & $\begin{array}{l}\text { Traditional } \\
\text { microbiological } \\
\text { assays }\end{array}$ & $\begin{array}{l}\text { Proadrenomedullin } \\
\text { levels }\end{array}$ & 88 children & $100 \%$ & $70 \%$ & - & - & - \\
\hline Li et al. (23) & $\begin{array}{l}\text { Diagnosing } \\
\text { COVID-19 }\end{array}$ & RT-qPCR & $\begin{array}{l}\text { CRP and } \\
\text { leukocyte count }\end{array}$ & $\begin{array}{l}\text { 3-gene transcript } \\
\text { signature }\end{array}$ & 228 adults & $88.6 \%$ & $94.1 \%$ & - & - & \\
\hline McClain et al. (24) & $\begin{array}{l}\text { Early detection } \\
\text { and treatment of } \\
\text { influenza (in the } \\
\text { pre-symptomatic } \\
\text { phase) }\end{array}$ & $\begin{array}{l}\text { GeneChip Human } \\
\text { Genome U133A } \\
\text { Array (microarray) }\end{array}$ & Standard methods & 50-gene signature & $\begin{array}{l}21 \text { healthy adults } \\
\text { inoculated with } \\
\text { influenza }\end{array}$ & - & - & - & & $\begin{array}{l}\text { Demonstrating } \\
\text { temporal } \\
\text { dynamics between } \\
\text { gene signatures } \\
\text { and early } \\
\text { treatment }\end{array}$ \\
\hline Tang et al. (25) & $\begin{array}{l}\text { Influenza vs. } \\
\text { bacterial infections }\end{array}$ & $\begin{array}{l}\text { Integrated } \\
\text { genomic analysis }\end{array}$ & Standard methods & 1-gene (IFI27) & 1,071 individuals & $88 \%$ & $90 \%$ & - & - & $\begin{array}{l}\text { Diagnostic } \\
\text { accuracy of this } 1 \\
\text { gene signature } \\
\text { equivalent to using } \\
\text { multi-gene } \\
\text { biomarkers }\end{array}$ \\
\hline $\begin{array}{l}\text { Barral-Arca et al. } \\
\text { (26) }\end{array}$ & $\begin{array}{l}\text { Diagnosing RSV } \\
\text { infection }\end{array}$ & $\begin{array}{l}\text { Meta-analysis of } \\
7 \text {-transcriptome } \\
\text { microarrays from } \\
\text { whole blood } \\
\text { samples }\end{array}$ & & $\begin{array}{l}\text { 17-transcript host } \\
\text { genes }\end{array}$ & 922 samples & $81.3 \%$ & $93 \%$ & - & - & - \\
\hline Sweeney et al. (27) & $\begin{array}{l}\text { Non-sputum } \\
\text { host-based } \\
\text { diagnostics for } \\
\text { active } \mathrm{Tb}\end{array}$ & $\begin{array}{l}\text { Integrated } \\
\text { multicohort } \\
\text { analysis of existing } \\
\text { gene expression } \\
\text { microarray from } \\
\text { peripheral blood }\end{array}$ & $\begin{array}{l}\text { Traditional } \\
\text { growth-based } \\
\text { microbiology } \\
\text { diagnostics }\end{array}$ & 3-gene signature & 2,572 patients & $93 \%$ & $97 \%$ & - & - & - \\
\hline $\begin{array}{l}\text { Warsinske et al. } \\
\text { (28) }\end{array}$ & $\begin{array}{l}\text { Using the 3-gene } \\
\text { signature in Rossi } \\
\text { et al. (29) for } \\
\text { studying treatment } \\
\text { response and } \\
\text { progression of } \\
\text { latent to active Tb }\end{array}$ & $\begin{array}{l}\text { qPCR and RNA } \\
\text { sequencing }\end{array}$ & $\begin{array}{l}\text { Traditional sputum } \\
\text { conversion }\end{array}$ & 3-gene signature & 363 subjects & $86 \%$ & $84 \%$ & - & $99.3 \%$ & $\begin{array}{l}\text { This assay showed } \\
\text { accurate diagnosis } \\
\text { of active to latent } \\
\text { Tb progression } 6 \\
\text { months earlier } \\
\text { than traditional } \\
\text { sputum } \\
\text { conversion }\end{array}$ \\
\hline
\end{tabular}


diagnostics for the detection of COVID-19. In one study, the aim was to derive a transcriptional signature to detect multiple viral infection among including COVID-19. Whole-blood RNA sequencing on samples from subjects was performed with confirmed bacterial, viral or no infection cases. Signature host genes were derived and validated using RT-qPCR. Threesignature genes (IGF1R, NAGK, and HERC6) were derived from the subjects enrolled by differential gene expression analyses using forward selection-partial least squares. The $I F G 1 R$ represents an insulin signaling tyrosine kinase protein that has shown to act as an entry receptor for respiratory syncytial virus (RSV) as well as macrophage and phagocytosis activation. NAGK is an enzyme responsible for amino acid metabolism, and HERC6 has been reported to have antiviral activity when induced by interferon. These gene transcripts distinguished bacterial from viral infections with a $97.3 \%$ sensitivity and $100 \%$ specificity with superior performance to CRP and leukocyte count. A second validation analysis was done, and the 3 gene signature distinguished between bacterial and COVID-19 positive subjects with a sensitivity of $88.6 \%$ and a specificity of $94.1 \%$ also outperforming CRP levels and leukocyte count (23).

In one recent study of COVID-19 infected subjects, RNA-sequencing was used to assess the host response in nasopharyngeal and whole blood samples. This technique allowed the derivation of a 19-gene host-response classifier that can differentiate COVID-19 infection from other infections with an accuracy of $86.5 \%$, sensitivity of $80 \%$ and specificity of $90 \%$ using NP samples. The dysregulated immune response with COVID-19 showed a distinct pattern of activation and inhibition of immune pathways as compared to other infections such as influenza, seasonal coronaviruses, and bacterial sepsis. Moreover, the magnitude of the host-response was found to be directly proportional with clinical severity of the disease. Remarkably, an increased expression of genes involved in interferon responses and decreased expression of IL-6 and IL-18 signaling was noted. Other genes such as ACE2 and TMPRSS2 have shown an association with the need of oxygen therapy during COVID-19 as well as predicting disease severity. However, these genes did not necessarily prove to be upregulated in COVID-19, whether from whole blood or nasopharyngeal swab. The results show that the expression of both genes can serve a prognostic rather than diagnostic role (29, 33).

Such a study points out to the potential of using classifiers of host-response for diagnosis of COVID-19 in the presymptomatic or asymptomatic stage during which $38 \%$ of pathogen-based PCR will turn out negative (33).

\section{Influenza and Respiratory Syncytial Virus}

Influenza virus, known as "the flu" is one of the most common seasonal respiratory infections worldwide (34). The average pre-symptomatic incubation period of influenza is 2 days. Oseltamivir, a neuraminidase inhibitor, is a therapeutic intervention used in the pre-symptomatic phase shows reduction in the progression of disease, decrease symptoms, infectivity, and accelerated resolution of disease. Early identification of influenza-infected individuals would permit more effective use of antiviral interventions. The use of host-based immune response for early detection of influenza was examined including the implications on management and therapy. Subjects were intranasally inoculated with influenza $\mathrm{A}$ and host gene expression was then assessed in peripheral blood samples every $8 \mathrm{~h}$ for 7 days using the GeneChip Human Genome U133A Array (Affymetrix, Santa Clara, CA), which is a single array representing 14,500 genes. This process led to the derivation of a gene signature expression for influenza virus composed of 50 genes. The host inflammatory response represented by the gene signature derived was then monitored after the early therapeutic use of oseltamivir in inoculated subjects. It was noted that the markers of host response were significantly reduced upon early treatment with oseltamivir demonstrating a correlation between disease activity, symptoms over time and overall expression of gene-signature levels. The level of host-gene expression was in agreement with the trajectory of symptom progression, thus showing the significance of the impact of time on host-response diagnostics. Although the application of such a technology is complex, the use of a potential rapid and accessible platform (i.e., PCR-based assays) as described in this article could help overcome this limitation. This study is important for providing insight on the correlation of disease severity and gene signatures as well as demonstrating the temporal dynamics of genomic signatures and their response to early treatment (24).

The number of gene biomarkers required has also been examined. A single gene biomarker, IFI27, was used for discriminating between influenza and bacterial infections was identified using integrated genomic analysis. In vitro experiments have shown that IFI27 was expressed by antigen presenting cells responding to influenza virus. In vivo studies confirmed expression of IFI27 in influenza patients. In fact, in this prospective study enrolling patients with suspected respiratory illness, IFI27 showed high diagnostic accuracy of $88 \%$ and a specificity of $90 \%$ for distinguishing between influenza and bacterial infections equivalent to accuracy obtained by using multi-gene biomarkers (25).

Although IFI27 has demonstrated the potential of differentiating influenza virus from bacterial infections, other studies using the same gene marker in the context of other viral respiratory infections show similar results. In one study of preterm RSV-infected infants, IFI27 was highly expressed, and its expression correlated with the severity of the disease (35).

Moreover, in another multi-cohort observational study, IFI27 was shown to be expressed in COVID-19 infected patients, and its level of expression was associated with the presence of a high viral load (36). These results are promising although further validation is required to achieve high specificity of this gene marker to a particular disease.

Since IFI27 has been found to be upregulated in influenza, RSV and COVID-19, an effort to identify a single-gene biomarker with a high diagnostic accuracy and specificity to influenza virus in one study was attempted. XGBoost integrated bioinformatics analysis was used to identify 14 genes specifically related 
to influenza infection using data from obtained from the gene expression Omnibus database. One gene, oligoadenylate synthetases-like (OASL), was further identified from the 14 gene set and was shown to differentiate between influenza and non-influenza viral and bacterial respiratory infections sharing comparable clinical features outperforming IFI27 with an AUC of 0.85 vs. 0.76 , respectively. OASL is known to possess antiviral mediated roles and has been recently shown to have a role in antiviral innate immunity, and it has been previously studied in the context of differentiating viral from bacterial infections. However, OASL's expression value measured by qRT-PCR can be sufficient to differentiate influenza from other non-influenza viral infections. Thus, this study presented significant results to identify OASL as a single biomarker for accurate and specific influenza virus identification (37).

Host-response profiling is not limited to diagnostic potential but also for predicting disease severity. In a study of RSV, the association between nasopharyngeal microbiota and host response profiles predicted the disease severity in RSV-infected children. Nasopharyngeal microbiota was characterized from children with mild and severe RSV using RNA sequencing. In turn, whole blood transcriptome profiles were analyzed to find the potential relationship between the microbiota, RSV host response and consequently, disease severity. RNA from whole blood was hybridized onto Illumina HT12-V4 bead chips.

The data revealed different nasopharyngeal microbiota clusters correlated with interferon related genes from the host response to RSV infections. A significant result overexpression of interferon genes related to neutrophil and macrophage activation in RSV infected children with $H$. influenza and Streptococcus dominant microbiota. This provides a demonstration of the possible interaction between the nasopharyngeal microbiota and the host response in RSV infected children ultimately in determining disease severity $(35,38)$.

A multi-cohort analysis approach for exploring host transcriptome biomarkers to derive a transcript-gene signature was undertaken as a better RSV diagnostic. Meta-analysis of 7 transcriptome microarray studies consisting of 922 whole blood samples from RSV, healthy, coronaviruses, rhinoviruses infected adults and children identified over 1,500 expressed genes from RSV-infected patients. Furthermore, selectively studying various pathways significantly affected by RSV yielded a 17 transcript host gene signature that is specific for RSV and can differentiate it from other respiratory infections. The results showed a sensitivity of $81.3 \%$ and a specificity of $93 \%$ for distinguishing RSV from other viral infections using this 17-transcript host signature (26).

In a similar manner, one study used whole blood mRNA signatures to assess the severity and pathogenicity of influenza virus. Certain signatures related to interferon antiviral pathways proved to be common in influenza cases not requiring intubation. As for those requiring mechanical ventilation support, inflammatory, activated neutrophil pattern was seen as early as possible in the course of the disease. Thus, using host-based profiling can potentially project the clinical course of influenza and provide insight on therapeutic tools for severe cases $(38,39)$.

\section{Host-Based Diagnostics for Identifying Mycobacterium tuberculosis}

Mycobacterium tuberculosis (M. tuberculosis) is a potentially lifethreatening infectious disease with typical pulmonary primary infection. The use of host-immune based diagnostics to support the identification of $M$. tuberculosis, disease severity and treatment response was assessed. The focus of these novel diagnostic models was on the ability of improved sensitivity for the detection of smaller disease signatures with higher discriminatory power (40).

The World Health Organization (WHO) identified the need for non-sputum-based diagnostic tests for better diagnosis of M. tuberculosis and for differentiating active from latent disease states. The need for new non-sputum diagnostics for active M. tuberculosis is realized by the difficulty and poor sensitivity of traditional growth-based microbiology approaches. In an integrated multicohort analysis of existing gene expression microarray from peripheral blood of patients with active $M$. tuberculosis composed of 2,572 patient samples, deriving a diagnostic gene set was attempted. Patients with latent $M$. tuberculosis and other diseases (i.e., sarcoidosis, autoimmune infections, lung cancer) were compared to those with active $M$. tuberculosis using the available multicohort analysis framework. Following analysis, a three gene set out of 266 demonstrated significantly higher diagnostic accuracy for active vs. latent M. tuberculosis from whole blood. These 3 genes were GBP5, DUSP3, and KLF2. GBP5 is a protein coding gene known to activate inflammasome assembly and reported to have a role in innate immunity and inflammation. Similarly, DUSP3, a protein phosphatase, and KLF2 play a role in modulating innate immunity. This dataset distinguished active M. tuberculosis from healthy subjects with a sensitivity of $93 \%$ and a specificity of $97 \%$. Such a gene set could potentially offer a framework for better diagnosis and treatment response to active M. tuberculosis (27).

In a similar study, published gene signatures for active M. tuberculosis diagnosis were identified using unbiased screens. Sixteen gene signatures were found. Twenty-four datasets containing 3,083 transcriptome profiles from whole and peripheral blood of healthy, active $M$. tuberculosis, latent M. tuberculosis and other diseases subjects were screened. A similar conclusion was made with the 3 signature genes (GBP5, DUSP3, and KLF2) described above demonstrating significant discrimination in identifying subjects with active $M$. tuberculosis and in predicting those with high risk of progression from latent to active $M$. tuberculosis with a sensitivity of $90 \%$. These results demonstrated superiority over traditional sputum tests with a sensitivity of $53.3 \%$ (28).

This three-gene M. tuberculosis score was further tested in a cohort study for performance, not only as a diagnostic, but as an indicator for $M$. tuberculosis treatment response and on post-treatment residual inflammation. The three-gene $M$. tuberculosis score detected patients with active M. tuberculosis with a negative predictive value (NPV) of $99.3 \%$ at a prevalence of $4 \%$. Additionally, with a sensitivity of $86 \%$ and a specificity of $84 \%$, the three-gene mRNA expression score measured by qPCR or RNA sequencing showed accurate diagnosis of progression of 
latent to active $\mathrm{Tb}$ with an $86 \%$ sensitivity and $84 \%$ specificity, 6 months earlier than traditional sputum conversion which has a lower sensitivity of 45-61\% (41) (see Table 2).

Moreover, soluble protein biomarkers such as interferoninducible protein 10 (IP-10) have shown high sensitivity (98\%) and specificity (87\%) for $\mathrm{Tb}$ infection with superior sensitivity compared to interferon gamma-based IGRA test (42). In fact, in a recent study of $M$. tuberculosis infection, the aim was to identify host biomarkers for discrimination between latent and active M. tuberculosis. Using PCR assays on serum and saliva samples from active $M$. tuberculosis patients and their contacts, numerous chemokines, cytokines, and growth factors were assessed. Results were favorable for differentiating latent and active $M$. tuberculosis using interferon-inducible protein 10 IP-10 and B-Cell attracting chemokine (BCA-1) in serum with an AUC of 0.83 , specificity of $88 \%$ and sensitivity of $72 \%$. Moreover, testing for IP-10 in saliva showed an AUC of 0.68 , sensitivity of $52 \%$ and specificity of $68 \%$. This provides additional insight on the role of host-response diagnostics on differentiating latent vs. active M. tuberculosis infections $(43,44)$.

\section{Host-Based Immunodiagnostics in Sepsis}

Host immune-based diagnostics have also been studied in sepsis, a potentially life-threatening process in the setting of serious infections. Using MeSH terms for sepsis, host-response, and infections we have found 5 citations of studies.

The InSep test (previously mentioned in section "a") provides better insight to guide decision making. The host data, reflecting activation of immunity, can offer more real-time guidance for antimicrobial stewardship programs in management of appropriate antibiotic usage reduction of antimicrobial resistance and drug side effect. In addition, the rapid turnaround time allows for efficient diagnosis of sepsis along with determination of prognosis and disease severity $(7,8)$.

Multiple clustering analysis from host transcriptomics in a retrospective study of patients with bacterial sepsis revealed three robust clusters. These subtypes were derived from a unified clustering analysis across 14 discovery datasets. The three robust clusters were termed "Inflammopathic," "Coagulopathic," and "Adaptive." Such clusters represent the heterogeneity of sepsis, and each subtype is associated with different mortality rates and different clinical coagulopathy rates. The "Inflammopathic" cluster was associated with higher mortality and an innate immune activation; the "Coagulopathic" cluster was associated with higher mortality, older patients and evidence of coagulopathy, and the "Adaptive" cluster showed an association with lower mortality and adaptive immune activation. These results represent a broad definition of the hostresponse to sepsis (45).

In a similar manner, studies using single-cell RNA sequencing of peripheral blood from subjects with sepsis defined 16 immune cell states. Using monocytes and dendritic cells, the outcome attained was identification of a sepsis specific CD14+ monocyte state. This monocyte state has specific surface markers and ultimately demonstrates that use of single-cell RNA sequencing can lead to the identification of unique disease associated cytologic signatures in bacterial sepsis (46).
Sepsis is a process that is not just limited to the adult population; in fact, neonates are at increased risk for developing sepsis. The complexity and ambiguity of the neonatal immune response has made it difficult to diagnose infections. There is no single biomarker that has yet proven to perform with sufficient accuracy for ruling out pediatric sepsis. Using host whole blood expression for 11 gene (Sepsis MetaScore, company, city, state), pediatric patients with sepsis were evaluated. The Sepsis MetaScore showed higher accuracy in diagnosing sepsis among 3 cohorts of neonates from several different countries as compared to standard neonatal lab tests. The sensitivity and specificity were 95 and $60 \%$, respectively, as compared to standard microbiological testing with a sensitivity of $70 \%$ for a leukocyte count $>15,000$ and $<3,000$, and a sensitivity of $90 \%$ for $\mathrm{CRP}>10 \mathrm{mg} / \mathrm{L}$. As for adults, implementing such improved diagnostics would lead to less AMR as well as decreased neonatal mortality rates (47).

\section{Effect of Host-Based Diagnostics on Healthcare Cost and Public Health Measures}

The impact of host-based diagnostics has also been studied economic and public health outcomes in four studies.

Host-based immunodiagnostics were used to examine high risk close contact exposures. Participants who were in proximity of patients diagnosed with a respiratory viral infection were recruited, and a blood based 36 gene RT-PCR assay as a transcriptomic biomarker was used in an attempt for early identification of viral infection. The results were promising and have shown that such an assay can serve as an accurate prediction for viral infection at both the time of maximum symptom severity as well as up to 3 days before symptoms arise when compared to definite viral infection confirmed by PCR. This transcriptomic assay predicted viral infection at the peak symptom severity with an AUROC of 0.94 , at 1,2 , and 3 days before symptoms arise with an AUROC of 0.87, 0.85, and 0.74 , respectively. This study was the first real-world study to show that a host gene expression-based assay can accurately predict a respiratory viral infection before typical symptoms are present (48).

From an economic point of view, HostDx ${ }^{\mathrm{TM}}$ Sepsis (Inflammatix, Inc., city, state), a multi-RNA host response expression platform, was compared to the standard of care including procalcitonin. Results showed substantial reduction of average cost estimated to be around a \$1974 USD per patient. Excluding the cost of the test itself, this overall healthcare cost reduction was attributed to a shorter stay at the hospital, decrease mortality rates at 30 days and less antibiotics being prescribed $(7,49)$. Additionally, a decline in the number of blood cultures drawn can be achieved, as well as mechanical ventilation and ICU stay days.

Moreover, platforms utilizing two-gene transcript RNA signature translated to RT-LAMP can prove to be cost-effective (due to absence of fluorescent label) with an average assay cost of, \$1.33 USD per chip (17). 


\section{Integrating Host-Based Diagnostics With Pathogen-Based Testing for Improved Clinical Outcomes}

Despite the recent rise attention on host-based diagnostics, pathogen-based diagnostics continue to be the gold standard and the most frequently used assays for infectious disease detection. Therefore, being able to integrate host-based with pathogenbased diagnostics for increased sensitivity and better outcomes is an area of active investigation.

In a prospective cohort study of critically ill patients with acute respiratory failure, a combination of three elements: pathogen, host gene expression signatures and the airway microbiome using a developed sequencing-based approach was studied. The hypothesis of the study states that the combination of host response testing with simultaneous detection of possible respiratory pathogens and measurement of lung microbiome diversity could serve as a more precise and accurate platform for infection. In the host-response, upregulation of pathways related to 414 expressed genes was shown in the LRTI patients. These sets of transcriptional signatures differentiated LRTI subjects from the non-LRTI group which showed another set of upregulated pathways. On the other hand, the LRTI prediction using pathogen diagnostics was based on a logistic regression model. A logistic regression model microbial score was derived to classify subjects as having lower respiratory tract infection or not. The third element was lung microbiome diversity, and the rationale based on several studies is that a reduction in the diversity of the airway microbiome occurs in the setting of an active infection. This diversity was denoted by $\alpha$ and was measured using a diversity index using RNA-sequencing which showed more diversity for LRTI than non-LRTI enrolled patients.

Metagenomics next generation sequencing was next applied to integrate these three core elements. mNGS was used to identify microbial species. However, the presence of bacterial components in a blood specimen does not necessarily explain the cause of the patient's disease due to possibility of contamination or translocation of commensal bacteria to the bloodstream. In a similar manner, viral sequencing can detect clinically irrelevant or latent viruses in the bloodstream and thus would not explain the patient's disease. Therefore, complementing mNGS that detect microbes with host RNA transcript-based profiling using RNA signatures can provide better results in detecting infected patients, differentiating bacterial vs. viral infections.

The results of this integration resulted in a 36\% reduction in antibiotics use, higher accuracy for identifying LRTI positive patients as compared to the standard of care. The detection of pathogens otherwise not usually tested for using classic viral PCR assays (i.e., influenzae C). The specificity and sensitivity of this assay were 87.5 and $100 \%$, respectively. Therefore, the results of this study suggested using an integration protocol for these three elements of LRTI can operate as a promising and superior tool in the management and outcomes of LRTI patients (50-52).

Similarly, integrating mNGS for detecting bacterial DNA, host response profiling using previously defined host response transcript signatures and viral capture sequencing was performed in a prospective study of 200 patients enrolled from the ED with suspected sepsis. Study results show that each of the 3 techniques used showed an improvement of diagnosis of sepsis, and when used in combination, an even better improvement in diagnosis and management of sepsis was noted. One notable result of this study was that host response profiling led physicians to change their diagnostic decisions in 46 out of 100 patients highlighting the impact of host response profiling in the management of patients with suspected sepsis (52).

\section{Other Diagnostic Methods}

Finally, the focus of this review is molecular assays based on the host immune response, although it is noteworthy to mention that advances in specific imaging modalities utilizing "omics" technology have contributed to improved microbial detection. A major step in the technological progress may be the implementation of $7 \mathrm{~T}$ MRI imaging to investigate microbiological processes by sampling parameters of cell and tissue metabolism that are dynamic and subject to changes within certain cellular conditions such as infections (53).

\section{DISCUSSION}

A dynamic and temporal relationship between infectious processes and the host-immune response has been described in this review. Taking into consideration the impact of the host-response, attempts of using it as a reference for applying a more individualized approach of precision medicine has become the focus of many research studies. Using advanced assays that include RT-PCR, single cell RNA sequencing, mNGS, microarrays and RT-LAMP were reviewed and show high levels of accuracy compared to gold standard. Host-gene signatures, transcriptomics, proteomics, and expressed biomarkers used demonstrate promising results for a systematic integration of host immunodiagnostics with conventional microbial detection for improved management of infectious diseases. Host-based response may serve to be an alternative of the traditional timeconsuming microbiological assays. However, a more holistic approach would be the integration of both host and pathogenbased diagnostics into one single platform. Future studies and clinical trials will be required to measure the true impact of combining these approaches.

One of the most important uses of the host-response as a tool for improving diagnostics has been the focus on the discrimination between bacterial and viral infections. Several studies were described in this review article that allow for the accurate discrimination of bacterial vs. viral etiologies in suspected infection. In fact, potential results of host-based diagnostics in this matter can achieve the WHO goal of ending tuberculosis in 2,035 if correctly implemented for superior pathogen diagnosis (27).

Accurate and rapid discrimination between bacterial and viral infections can also direct management by permitting proper antibiotics usage and prescription in a timely and directed manner. Ultimately, the improved patient outcome with higher and more rapid cure rates may translate into decreased mortality rate, healthcare costs for prolonged hospital stay, and the decrease in antibiotics misuse. 
Host-based diagnostics have also shown major success in the diagnosis of sepsis. Considered a life-threatening process, sepsis calls for immediate life-saving intervention measures. Applying host-based diagnostics was shown to assist with the determination of the underlying etiology of sepsis as well as providing insight on the severity and prognosis.

Another important manifestation of host-immune diagnostics that has been highlighted in this review is the ability to distinguish latent infection from active infection as well as predicting the progression from latent to active infection at an earlier stage than standard microbiological tests. This should be an important aspect for future consideration that may necessitate a different approach with latent infections' management and prognosis.

Additionally, host gene signatures contribute to identification of treatment response over elapsed time as well as disease progression. This ability to measure response can prove to play an important role in determining staging of an infectious disease, its severity and its response to treatment.

This review also highlighted the potential of host-microbiota signatures to provide a perception of the severity and prognosis of certain infections. Although further future validation is required, such a link could facilitate the implementation of assays using microbial signatures to prognosticate respiratory infections concurrently with diagnostics for such infections.

From an economic perspective, host-based diagnostics may significantly reduce healthcare costs. Through improved definition of host response, more sensible use of antibiotics will ultimately lead to a reduction in the drug cost as well as antibiotic administration. Moreover, improved accuracy will likely lead to a decrease in the usage of consultation services as well as excessive procedures and laboratory tests being ordered (e.g., interventional radiology procedures, inflammatory markers, tumor markers, biopsies). These interventions may result in an overall decrease in cost on the individualized patient level and on the overall healthcare industry, although additional clinical trials will be required. In future applications, immunodiagnostics, unlike pathogenbased testing, may present the capability of differentiating non-infectious immune triggers including sterile inflammatory processes, autoimmune diseases, or malignancy. Further improvement in the currently existing platforms is required before such a claim can be translated into clinical practice and to possibly supersede and replace standard pathological techniques for such non-infectious causes.

One other advantage for host-response diagnostics as compared to pathogen-based diagnostics arises from the ability of viruses to mutate at a fast rate with emergence of different variants. Some RNA viruses can have a mutation rate up to a million times higher than their hosts and can incorporate mutated nucleotides at a rate of $10^{-6}-10^{-4}$ substitutions per nucleotide per cell infection (54). This ability of viruses to rapidly mutate and transfer between hosts imposes a limitation for their detection and requires the development of dynamic means to detect current and emergent viral strains. Using the host as the diagnostic subject overcomes this limitation and proves yet another firm basis for adopting such methods.
Finally, host-based diagnostics can help resolve multiple public health issues. A major effect of adopting more recent hostbased diagnostics is preventing further AMR which is one of the most serious global public health threats. By providing accurate diagnostic outcomes, more precise and targeted therapies could be applied, thus, reducing the risk antibiotic overuse and the emergence of AMR. At a hospital, country or global scale, host-response diagnostics may also play a role in the rapid identification of exposure which can result in containment and improved infection control measures, especially in the setting of epidemics and/or pandemics. Several studies have shown more rapid results of testing the host response for infectious processes than traditional microbiology assays. This approach has proven to be essential in the case of viral infections with long incubation periods and those characterized with presymptomatic yet highly contagious phases. Using such assays could prove to help with infection containment during viral pandemics or influenza season. The early detection of the nature of an infectious disease would help aid determining which patients require early quarantine, and this would ultimately be reflected as better patient care during possible pandemics such as COVID-19 (7). Detecting such affected individuals will help in the quarantine process and put a limit for the transmission of diseases. The COVID-19 pandemic has uncovered the severe lack of means and the desperate need of public health measures that deal with phenomena of such impact and scale (see Figure 1).

\section{POTENTIAL DOWNFALLS}

As with other assays, host-based diagnostics have shortcomings. An important limitation in multiple studies is lack of adequate sample size and concern for appropriate power resulting in a possible increase in the margin of error. Larger cohorts in prospective studies are required to improve the robustness of study performance estimates.

Another limitation is the absence of special populations including immunocompromised hosts such as solid organ, stem cell transplant recipients and those individuals with autoimmune disorders. These patients are at risk for expanded infections including invasive fungal pathogens, which are not represented in current studies and require future investigation.

Among the drawbacks of host response-based diagnostics is the lack of precise identification of the pathogen involved. This prevents directed and specific treatment of the causative agent (19). Moreover, despite promising outcomes in differentiating bacterial vs. viral infections and thus limiting the use of antibiotics in case of viral infections, the lack of precise identification of the causative pathogen and ultimately the lack of isolation of such pathogen in the case of bacterial infection prevents the assessment of its sensitivity to antibiotics. This would impose a limitation to reducing antimicrobial resistance.

Cost and technical limitations exist to these assays. For RNA-sequencing techniques, high cost are major barriers to adoption, specifically in areas with limited resources. The development of inexpensive platforms would improve the prospects of more rapid utilization in 


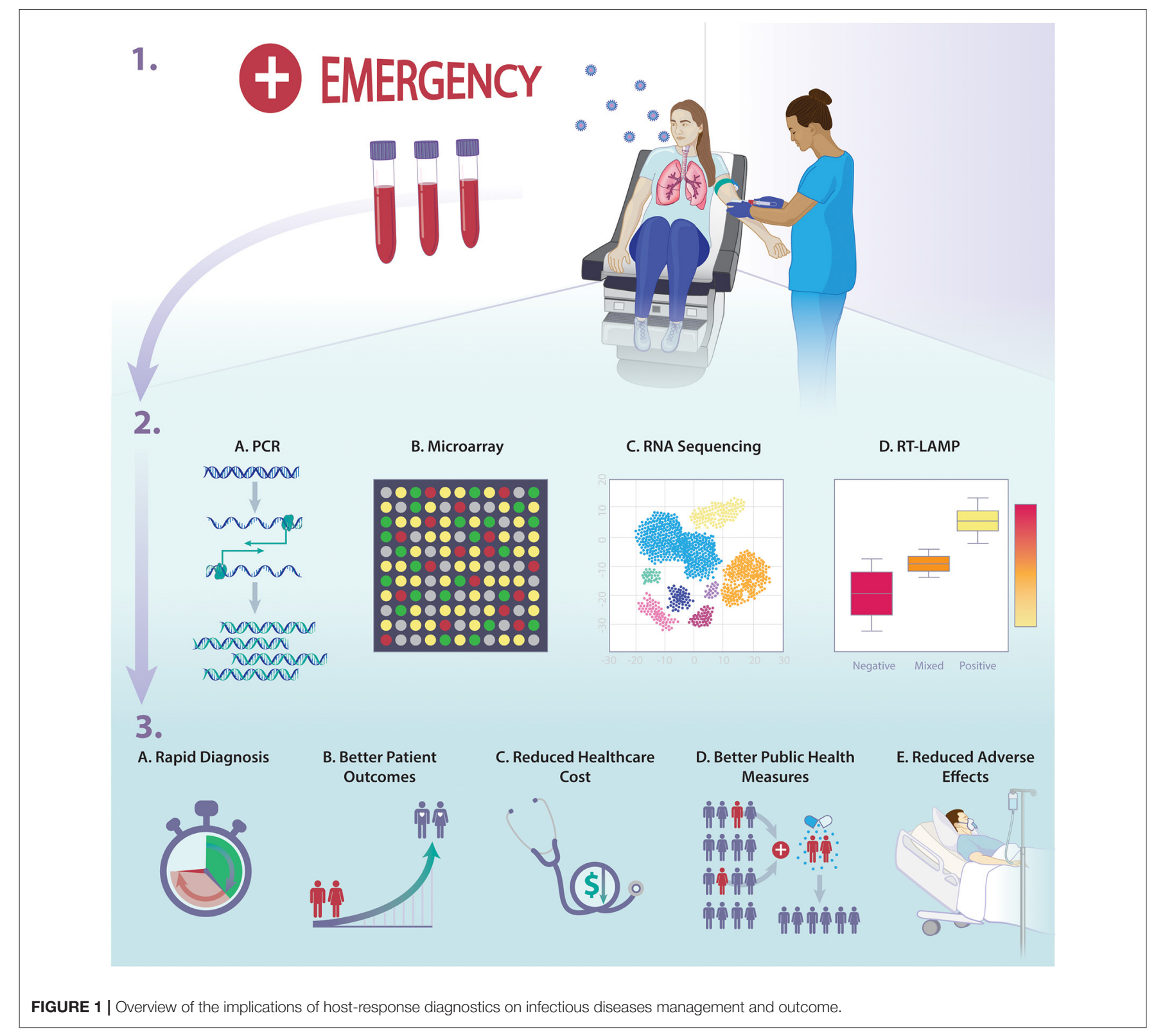

healthcare setting. Additionally, some platforms are tuned to specific set of biomarkers, which make generalizability for detection of other diseases potentially difficult. Finally, microarrays are currently far too time-consuming with a turnaround time of about 1-2 weeks to be applied in a clinical setting (55). Thus, further laboratory validation should be attained before any of these assays can be used in clinical settings.

\section{CONCLUSION}

This review describes multiple aspects of host-based response diagnostics as an adjunct to pathogen-based diagnostics and not as a replacement. However, favorable outcomes show that there are advantages of using host-based diagnostics as compared to pathogen-based diagnostics. Over 30 trials have focused on the use of host-response diagnostics for improved diagnosis of acute infection. Rapid and accurate diagnosis and prognosis can result in reduced healthcare costs, fewer adverse effects, reduction in antibiotic misuse and lower rates of antimicrobial resistance, improvement in public health measures for rapidly spreading endemics and pandemics, and ultimately better management with positive patient outcomes are potentials of adopting host immunodiagnostics. However, there remains some pitfalls including accessibility, cost, laboratory practicality and further clinical validation. While host immunodiagnostics show excellent promise, further investigations are needed to define the 
possible implications of adopting these novel modalities for the advancement in the field of infectious diseases.

\section{AUTHOR CONTRIBUTIONS}

JA drafted the original manuscript, responsible for article curation, and investigation. JA and MM revised and edited the draft. MM supervised and validated the final product. All authors

\section{REFERENCES}

1. Ramilo O, Mejias A. Host transcriptomics for diagnosis of infectious diseases: one step closer to clinical application. Eur Respir J. (2017) 49:1700993. doi: 10.1183/13993003.00993-2017

2. Sweeney TE, Khatri P. Generalizable biomarkers in critical care. Crit Care Med. (2017) 45:934-9. doi: 10.1097/CCM.0000000000002402

3. Ross MH, Zick BL, Tsalik EL. Host-based diagnostics for acute respiratory infections. Clin Ther. (2019) 41:1923-38. doi: 10.1016/j.clinthera.2019.06.007

4. de Jonge JC, de Lange DW, de Vaate EAB, van Leeuwen H, Arends JE. [Procalcitonin as biomarker for infections]. Ned Tijdschr Genees. (2016) 160:D282. doi: 10.3904/kjim.2013.28.3.285

5. Tsalik EL, Henao R, Montgomery JL, Nawrocki JW, Aydin M, Lydon EC, et al. Discriminating bacterial and viral infection using a rapid host gene expression test*. Crit Care Med. (2021) 49:1651-63. doi: 10.1097/CCM.0000000000005085

6. Tsalik EL, Henao R, Aydin M, Bullard C, Montgomery J, Nawrocki J, et al. 2012 FilmArray $\AA$ measurement of host response signatures rapidly discriminates viral, bacterial, and non-infectious etiologies of illness. Open Forum Infect Dis. (2018) 5:S586. doi: 10.1093/ofid/ofy210.1668

7. Ducharme J, Self WH, Osborn TM, Ledeboer NA, Romanowsky J, Sweeney TE, et al. A multi-mRNA host-response molecular blood test for the diagnosis and prognosis of acute infections and sepsis: proceedings from a clinical advisory panel. J Personalized Med. (2020) 10:266. doi: 10.3390/jpm10040266

8. Safarika A, Wacker JW, Katsaros K, Solomonidi N, Giannikopoulos G, Kotsaki A, et al. A 29-mRNA host response test from blood accurately distinguishes bacterial and viral infections among emergency department patients. Intensive Care Med Exp. (2020) 8:31. doi: 10.21203/rs.3.rs-128429/v1

9. Mayhew MB. A generalizable 29-mRNA neural-network classifier for acute bacterial and viral infections. Nat Commun. (2020) 11:1117. doi: 10.1038/s41467-020-14975-w

10. Bauer W, Kappert K, Galtung N, Lehmann D, Wacker J, Cheng HK, et al. A novel 29-messenger RNA host-response assay from whole blood accurately identifies bacterial and viral infections in patients presenting to the emergency department with suspected infections: a prospective observational study*. Crit Care Med. (2021) 49:1664-73. doi: 10.1097/CCM.0000000000005119

11. Sweeney TE, Wong HR, Khatri P. Robust classification of bacterial and viral infections via integrated host gene expression diagnostics. Sci Transl Med. (2016) 8:346ra91. doi: 10.1126/scitranslmed.aaf7165

12. Liu L, Oza S, Hogan D, Chu Y, Perin J, Zhu J, et al. Global, regional, and national causes of under-5 mortality in 2000-15: an updated systematic analysis with implications for the Sustainable Development Goals. Lancet Lond Engl. (2016) 388:3027-35. doi: 10.1016/S0140-6736(16)31593-8

13. Mahajan P, Kuppermann N, Mejias A, Suarez N, Chaussabel D, Casper TC, et al. Association of RNA biosignatures with bacterial infections in febrile infants aged 60 days or younger. JAMA. (2016) 316:846-57. doi: 10.1001/jama.2016.9207

14. Gómez-Carballa A, Cebey-López M, Pardo-Seco J, Barral-Arca R, RiveroCalle I, Pischedda S, et al. A qPCR expression assay of IFI44L gene differentiates viral from bacterial infections in febrile children. Sci Rep-uk. (2019) 9:11780. doi: 10.1038/s41598-019-48162-9

15. Herberg JA, Kaforou M, Wright VJ, Shailes H, Eleftherohorinou H, Hoggart CJ, et al. Diagnostic test accuracy of a 2-transcript host RNA signature for discriminating bacterial vs viral infection in febrile children. JAMA. (2016) 316:835-45. doi: 10.1001/jama.2016.11236 gave final approval of this version to be published and agreed to be guarantor of the work.

\section{FUNDING}

This work was supported, in part, by grants from the National Institute of Allergy and Infectious Diseases (RO1 AI132638) to MM.

16. Kaforou M, Herberg JA, Wright VJ, Coin LJM, Levin M. Diagnosis of bacterial infection using a 2-transcript host RNA signature in febrile infants 60 days or younger. JAMA. (2017) 317:1577-8. doi: 10.1001/jama.2017.1365

17. Pennisi I, Rodriguez-Manzano J, Moniri A, Kaforou M, Herberg JA, Levin M, et al. Translation of a host blood RNA signature distinguishing bacterial from viral infection into a platform suitable for development as a point-of-care test. JAMA Pediatr. (2021) 175:417-9. doi: 10.1001/jamapediatrics.2020.5227

18. Langevin S, Pichon M, Smith E, Morrison J, Bent Z, Green R, et al. Early nasopharyngeal microbial signature associated with severe influenza in children: a retrospective pilot study. J Gen Virol. (2017) 98:242537. doi: 10.1099/jgv.0.000920

19. Bhattacharya S, Rosenberg AF, Peterson DR, et al. Transcriptomic biomarkers to discriminate bacterial from nonbacterial infection in adults hospitalized with respiratory illness. Sci Rep-uk. (2017) 7:6548. doi: 10.1038/s41598-017-06738-3

20. Chen H, Yin Y, Gao H, Guo Y, Dong Z, Wang X, et al. Clinical utility of inhouse metagenomic next-generation sequencing for the diagnosis of lower respiratory tract infections and analysis of the host immune response. Clin Infect Dis. (2020) 71:S416-26. doi: 10.1093/cid/ciaa1516

21. Saeed K, Legramante JM, Angeletti S, Curcio F, Miguens I, Poole S, et al. Midregional pro-adrenomedullin as a supplementary tool to clinical parameters in cases of suspicion of infection in the emergency department. Expert Rev Mol Diagn. (2021) 21:1-8. doi: 10.1080/14737159.2021.1902312

22. Saleh MAA, van de Garde EMW, van Hasselt CJG. Host-response biomarkers for the diagnosis of bacterial respiratory tract infections. Clin Chem Lab Med Cclm. (2019) 57:442-51. doi: 10.1515/cclm-2018-0682

23. Li HK, Kaforou M, Rodriguez-Manzano J, Channon-Wells S, Moniri A, Habgood-Coote D, et al. Discovery and validation of a three-gene signature to distinguish COVID-19 and other viral infections in emergency infectious disease presentations: a case-control and observational cohort study. Lancet Microbe. (2021) 2:e594-603. doi: 10.1016/S2666-5247(21)00145-2

24. McClain MT, Nicholson BP, Park LP, Liu TY, Hero AO, Tsalik EL, et al. A genomic signature of influenza infection shows potential for presymptomatic detection, guiding early therapy, and monitoring clinical responses. Open Forum Infect Dis. (2016) 3:ofw007. doi: 10.1093/ofid/ofw007

25. Tang BM, Shojaei M, Parnell GP, Huang S, Nalos M, Teoh S, et al. A novel immune biomarker IFI27 discriminates between influenza and bacteria in patients with suspected respiratory infection. Eur Respir J. (2017) 49:1602098. doi: 10.1183/13993003.02098-2016

26. Barral-Arca R, Gómez-Carballa A, Cebey-López M, Bello X, MartinónTorres F, Salas A. A meta-analysis of multiple whole blood gene expression data unveils a diagnostic host-response transcript signature for respiratory syncytial virus. Int J Mol Sci. (2020) 21:1831. doi: 10.3390/ijms21051831

27. Sweeney TE, Braviak L, Tato CM, Khatri P. Genome-wide expression for diagnosis of pulmonary tuberculosis: a multicohort analysis. Lancet Respir Med. (2016) 4:213-24. doi: 10.1016/S2213-2600(16)00048-5

28. Warsinske H, Vashisht R, Khatri P. Host-response-based gene signatures for tuberculosis diagnosis: A systematic comparison of 16 signatures. PLoS Med. (2019) 16:e1002786. doi: 10.1371/journal.pmed.1002786

29. Rossi ÁD, de Araújo JLF, de Almeida TB, Ribeiro-Alves M, de Almeida Velozo C. Association between ACE2 and TMPRSS2 nasopharyngeal expression and COVID-19 respiratory distress. Sci Rep-uk. (2021) 11:9658. doi: 10.1038/s41598-021-88944-8

30. Alcoba G, Manzano S, Lacroix L, Galetto-Lacour A, Gervaix A. Proadrenomedullin and copeptin in pediatric pneumonia: a 
prospective diagnostic accuracy study. BMC Infect Dis. (2015) 15:347. doi: 10.1186/s12879-015-1095-5

31. Legramante JM, Mastropasqua M, Susi B, Porzio O, Mazza M, Miranda Agrippino G, et al. Prognostic performance of MR-pro-adrenomedullin in patients with community acquired pneumonia in the Emergency Department compared to clinical severity scores PSI and CURB. PLoS ONE. (2017) 12:e0187702. doi: 10.1371/journal.pone.0187702

32. Konings F, Perkins MD, Kuhn JH, Pallen MJ, Alm EJ, Archer BN, et al. SARSCoV-2 Variants of Interest and Concern naming scheme conducive for global discourse. Nat Microbiol. (2021) 6:821-3. doi: 10.1038/s41564-021-00932-w

33. Ng DL, Granados AC, Santos YA, Servellita V, Goldgof GM, Meydan $\mathrm{C}$, et al. A diagnostic host response biosignature for COVID-19 from RNA profiling of nasal swabs and blood. Sci Adv. (2021) 7:eabe5984. doi: 10.1126/sciadv.abe5984

34. Dangi T, Jain A. Influenza virus: a brief overview. Proc Nat Acad Sci India Sect B Biol Sci. (2012) 82:111-21. doi: 10.1007/s40011-011-0009-6

35. Gao J, Zhu X, Wu M, Jiang L, Wang F, He S. IFI27 may predict and evaluate the severity of respiratory syncytial virus infection in preterm infants. (2020) Hereditas. 158:1-14. doi: 10.21203/rs.3.rs-42880/v3

36. Shojaei M, Shamshirian A, Monkman J, Grice L, Tran M. IFI27 transcription is an early predictor for COVID-19 outcomes; a multi-cohort observational study. Medrxiv. (2021) 2021:10.29.21265555. doi: 10.1101/2021.10.29.21265555

37. Li Y, Liu H, Xu Q, Wu R, Zhang Y, Li $\mathrm{N}$, et al. OASL as a diagnostic marker for influenza infection revealed by integrative bioinformatics analysis with XGBoost. Front Bioeng Biotechnol. (2020) 8:729. doi: $10.3389 /$ fbioe.2020.00729

38. de Steenhuijsen Piters WA, Heinonen S, Hasrat R, Bunsow E, Smith B, Suarez-Arrabal MC, et al. Nasopharyngeal microbiota, host transcriptome, and disease severity in children with respiratory syncytial virus infection. Am J Resp Crit Care. (2016) 194:1104-15. doi: 10.1164/rccm.201602-0220OC

39. Dunning J, Blankley S, Hoang LT, Cox M, Graham CM, James PL, et al. Progression of whole-blood transcriptional signatures from interferoninduced to neutrophil-associated patterns in severe influenza. Nat Immunol. (2018) 19:625-35. doi: 10.1038/s41590-018-0111-5

40. Burel JG, Babor M, Pomaznoy M, Lindestam Arlehamn CS, Khan N, Sette A, et al. Host transcriptomics as a tool to identify diagnostic and mechanistic immune signatures of tuberculosis. Front Immunol. (2019) 10:221. doi: 10.3389/fimmu.2019.00221

41. Warsinske HC, Rao AM, Moreira FMF, Santos PCP, Liu AB, Scott M, et al. Assessment of validity of a blood-based 3-gene signature score for progression and diagnosis of tuberculosis, disease severity, and treatment response. JAMA Netw Open. (2018) 1:e183779. doi: 10.1001/jamanetworkopen.2018.3779

42. Blauenfeldt T, Villar-Hernández R, García-García E, Latorre I, Holm LL, Muriel-Moreno B, et al. Diagnostic accuracy of interferon gamma-induced protein 10 mRNA release assay for tuberculosis. J Clin Microbiol. (2020) 58:10. doi: 10.1128/JCM.00848-20

43. Estévez O, Anibarro L, Garet E, Pallares Á, Pena A, Villaverde C, et al. Identification of candidate host serum and saliva biomarkers for a better diagnosis of active and latent tuberculosis infection. PLOS ONE. (2020) 15:e0235859. doi: 10.1371/journal.pone.025859

44. Estévez O, Anibarro L, Garet E, Pallares Á, Barcia L, Calviño L, et al. An RNA-seq based machine learning approach identifies latent tuberculosis patients with an active tuberculosis profile. Front Immunol. (2020) 11:1470. doi: 10.3389/fimmu.2020.01470

45. Sweeney TE, Azad TD, Donato M, Haynes WA, Perumal TM, Henao R, et al. Unsupervised analysis of transcriptomics in bacterial sepsis across multiple datasets reveals three robust clusters. Crit Care Med. (2018) 46:91525. doi: 10.1097/CCM.0000000000003084
46. Reyes M, Filbin MR, Bhattacharyya RP, Billman K, Eisenhaure T, Hung DT, et al. An immune-cell signature of bacterial sepsis. Nat Med. (2020) 26:333-40. doi: 10.1038/s41591-020-0752-4

47. Sweeney TE, Wynn JL, Cernada M, Serna E, Wong HR, Baker HV, et al. Validation of the sepsis metascore for diagnosis of neonatal sepsis. J Pediatric Infect Dis Soc. (2017) 7:129-35. doi: 10.1093/jpids/pix021

48. McClain MT, Constantine FJ. A blood-based host gene expression assay for early detection of respiratory viral infection: an indexcluster prospective cohort study. Lancet Infect Dis. (2021) 21:396-404. doi: 10.1016/S1473-3099(20)30486-2

49. Schneider JE, Romanowsky J, Schuetz P, Stojanovic I, Cheng HK, Liesenfeld $\mathrm{O}$, et al. Cost impact model of a novel multi-mRNA host response assay for diagnosis and risk assessment of acute respiratory tract infections and sepsis in the emergency department. J Heal Econ Outcomes Res. (2020) 7:24-34. doi: 10.36469/jheor.2020.12637

50. Langelier C, Kalantar KL, Moazed F, Wilson MR, Crawford ED, Deiss T, et al. Integrating host response and unbiased microbe detection for lower respiratory tract infection diagnosis in critically ill adults. Proc National Acad Sci USA. (2018) 115:201809700. doi: 10.1101/341149

51. Penaranda C, Hung DT. Single-cell RNA sequencing to understand host-pathogen interactions. Acs Infect Dis. (2019) 5:336-44. doi: 10.1021/acsinfecdis.8b00369

52. Cheng HK. Combined use of metagenomic sequencing and host response profiling for the diagnosis of suspected sepsis. Biorxiv. (2019) 2019:854182. doi: 10.1101/854182

53. Hoerr V, Faber C. Magnetic resonance imaging characterization of microbial infections. J Pharmaceut Biomed. (2014) 93:13646. doi: 10.1016/j.jpba.2013.10.034

54. Cassedy A, Parle-McDermott A, O’Kennedy R. Virus detection: a review of the current and emerging molecular and immunological methods. Front Mol Biosci. (2021) 8:637559. doi: 10.3389/fmolb.2021.63 7559

55. Savage MS, Mourad MJ, Wapner RJ. Evolving applications of microarray analysis in prenatal diagnosis. Curr Opin Obstetrics Gynecol. (2011) 23:1038. doi: $10.1097 /$ GCO.0b013e32834457c7

Conflict of Interest: MM reports consultation fees from Safi Biosolutions, Clear Creek Bio, Vericel, NED biosystems, GenMark Diagnostics, and Day Zero Diagnostics; grant support from Thermo Fisher Scientific and Genentech; medical editing/writing fees from UpToDate, outside the submitted work. MM also reports patents 14/110,443 and 15/999,463 pending.

The remaining author declares that the research was conducted in the absence of any commercial or financial relationships that could be construed as a potential conflict of interest.

Publisher's Note: All claims expressed in this article are solely those of the authors and do not necessarily represent those of their affiliated organizations, or those of the publisher, the editors and the reviewers. Any product that may be evaluated in this article, or claim that may be made by its manufacturer, is not guaranteed or endorsed by the publisher.

Copyright (c) 2022 Atallah and Mansour. This is an open-access article distributed under the terms of the Creative Commons Attribution License (CC BY). The use, distribution or reproduction in other forums is permitted, provided the original author(s) and the copyright owner(s) are credited and that the original publication in this journal is cited, in accordance with accepted academic practice. No use, distribution or reproduction is permitted which does not comply with these terms. 